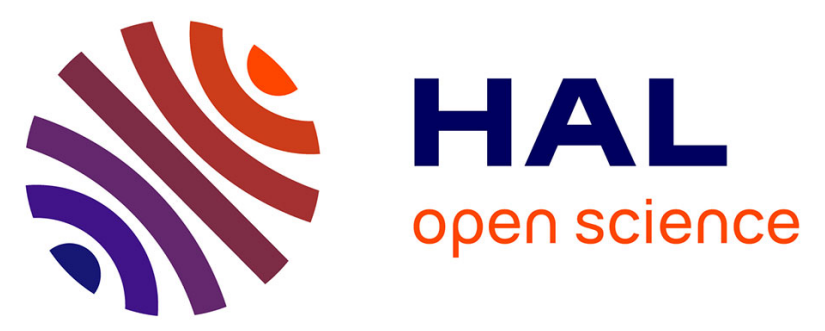

\title{
Impact of farmland fragmentation on rainfed crop allocation in Mediterranean landscapes: A case study of the Lebna watershed in Cap Bon, Tunisia
}

Insaf Mekki, Jean-Stéphane Bailly, Frédéric Jacob, Hichem Chebbi, Tarek

Ajmi, Yves Blanca, Abdelaziz Zairi, Anne Biarnès

\section{To cite this version:}

Insaf Mekki, Jean-Stéphane Bailly, Frédéric Jacob, Hichem Chebbi, Tarek Ajmi, et al.. Impact of farmland fragmentation on rainfed crop allocation in Mediterranean landscapes: A case study of the Lebna watershed in Cap Bon, Tunisia. Land Use Policy, 2018, 75, pp.772 - 783. 10.1016/j.landusepol.2018.04.004 . hal-01790352v2

\section{HAL Id: hal-01790352 \\ https://hal.science/hal-01790352v2}

Submitted on 22 Feb 2021

HAL is a multi-disciplinary open access archive for the deposit and dissemination of scientific research documents, whether they are published or not. The documents may come from teaching and research institutions in France or abroad, or from public or private research centers.
L'archive ouverte pluridisciplinaire HAL, est destinée au dépôt et à la diffusion de documents scientifiques de niveau recherche, publiés ou non, émanant des établissements d'enseignement et de recherche français ou étrangers, des laboratoires publics ou privés. 
Impact of farmland fragmentation on rainfed crop allocation in Mediterranean landscapes: A case study of the Lebna watershed in Cap Bon, Tunisia

Insaf Mekki ${ }^{* 1}$, Jean Stéphane Bailly ${ }^{2,3}$, Frédéric Jacob ${ }^{1,3}$, Hichem Chebbi ${ }^{1}$, Tarek Ajmi $^{1}$, Yves Blanca ${ }^{3}$, Abdelaziz Zairi ${ }^{1}$, Anne Biarnès ${ }^{3}$

${ }^{1}$ INRGREF, University of Carthage, Ariana, Tunisia

${ }^{2}$ AgroParisTech, 75005, Paris, France

${ }^{3}$ LISAH, Univ Montpellier, INRA, IRD, Montpellier SupAgro, Montpellier, France

\section{*Corresponding author:}

Insaf Mekki

National Research Institute for Rural Engineering, Water, and Forestry

INRGREF

B.P. 10. 2080, Ariana, Tunisia.

insaf.mekki@laposte.net

Published in Land Use Policy 75 (2018) 772-783

https://doi.org/10.1016/j.landusepol.2018.04.004

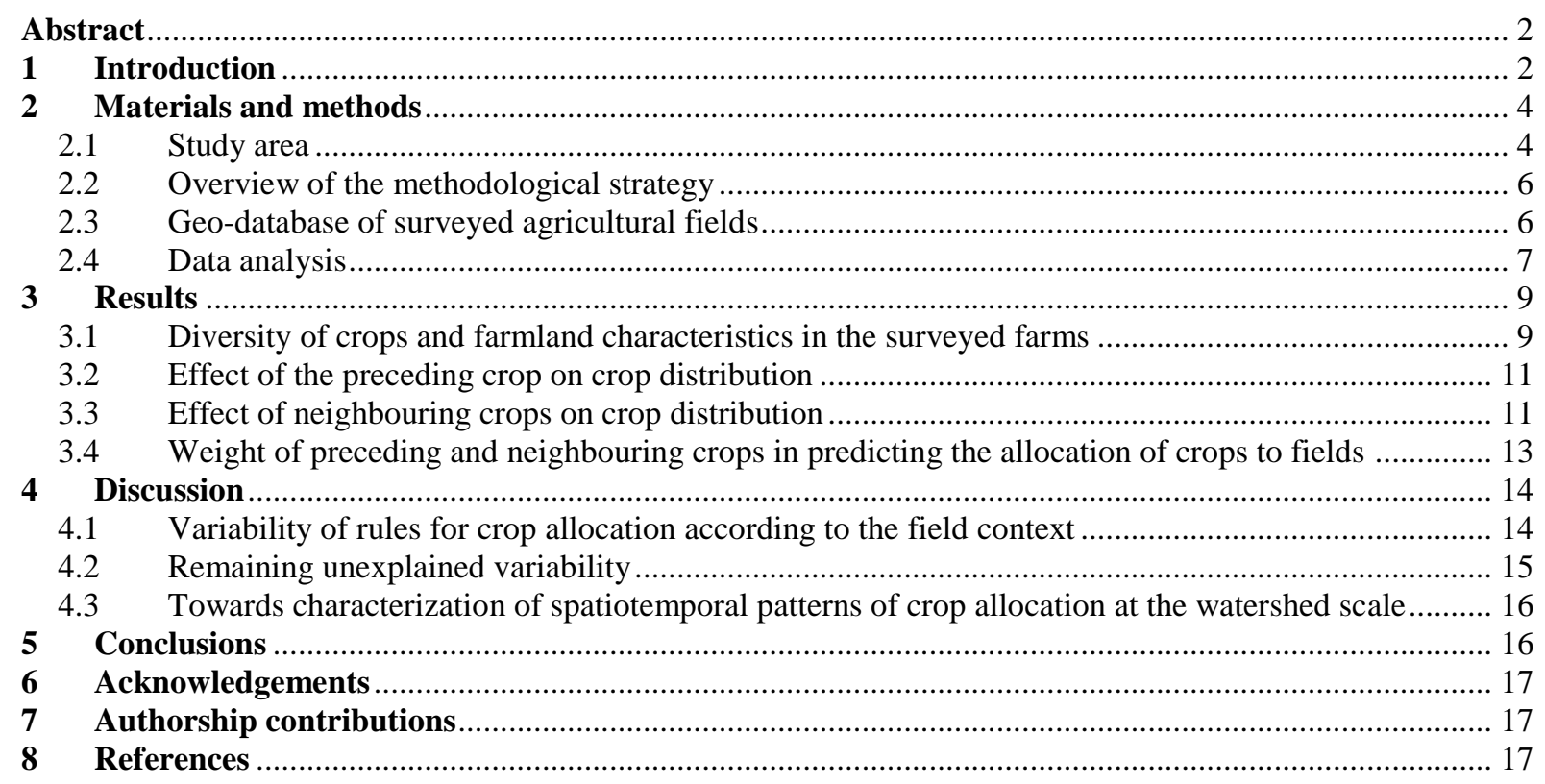




\begin{abstract}
Mediterranean agricultural landscapes provide ecosystem services and disservices that are driven by land use pattern dynamics, the latter of which results from the crop spatiotemporal distribution. Farmland fragmentation is known to be a driver of crop management and farm performance. However, existing studies on farmland fragmentation have not addressed the impact of farmland fragmentation and the subsequent neighbouring interactions on decision-making about annual crop allocation. Therefore, the current study aims to explore how much farmland fragmentation can drive the decisions made by farmer about annual crop allocation by characterizing and quantifying the influences of both crop sequences and neighbouring crops at the field scale. We addressed this issue within the Lebna watershed $\left(210 \mathrm{~km}^{2}\right.$ size, located on the Cap Bon Peninsula in Tunisia), which is typified by a hilly topography, rainfed mixed farming (cereals, fodder, legumes, spices) and livestock (cattle, sheep and goat), and strong farmland fragmentation. The experimental phases consisted of conducting 30 farmer interviews and collecting data regarding the field spatial distribution for a total number of 360 fields in 2015 and 355 fields in 2016, hereafter called farmer fields. We also recorded (1) crop types for the farmer fields in 2015 and 2016 and (2) land uses (including crop types) in the neighbouring pieces of land in 2016. Data analysis relied on differentiating the farmer fields between isolated and nonisolated fields. Isolation/non-isolation depended upon farmland fragmentation and field dispersion relative to the other farm fields and to the farmstead. Using univariate and linear discriminant analysis on both crop sequences and neighbouring crops, data analysis revealed a significant effect of farmland fragmentation on farmer decision-making regarding crop allocation. When fields are isolated (fragmented farmlands), farmers implement with some of their neighbours, collective rules of crop allocation that permit the management of common constraints, such as the lack of roads to access fields. The landscape subsequently depicts aggregates of fields with the same type of crop. When fields are non-isolated (aggregated farmlands close to the farmsteads), the allocation constraints are mainly related to the cropping systems, with a strong impact from the crop sequences. Overall, these results indicate that to improve our understanding of crop allocation drivers at the landscape level, it is not only sufficient to address rules and drivers at the field and farm scales but it is also necessary to account for the collective contexts in which farmers operate.
\end{abstract}

Keywords: Rainfed agrosystems; open fields; spatial distribution of crops; succession of crops; isolated/non-isolated farm fields; neighbouring effects.

\title{
1 Introduction
}

Agricultural landscapes provide ecosystem services and disservices that are driven by land use pattern dynamics resulting from crop spatiotemporal distribution (Millennium Ecosystem Assessment, 2005, IAASTD, 2009). Crop mosaics related to spatial patch arrangement and crop succession impact the sustainability of agricultural production (Jackson et al., 2007) as well as numerous biophysical processes such as water, erosion and contaminant fluxes (Joannon et al., 2006; Wohlfahrt et al., 2010; Colin et al., 2012), biotic diversity (Joannon et al., 2008) and gene fluxes (Viaud et al., 2008). Therefore, characterizing the drivers of crop allocation to fields is a prerequisite for (1) exploring and simulating spatially explicit plausible land use scenarios, and (2) quantifying the subsequent ecosystem services and disservices (Benoît et al., 2012; Rizzo et al., 2013).

As discussed in previous studies, land use pattern dynamics on agricultural landscapes result from crop allocation rules that are defined at the farm scale and that drive both the successions of crops over several years and the annual distributions of crops among farmlands (Joannon et al., 2008; Thenail et al., 2009; Castellazzi et al., 2010; Houet et al., 2010; Sorel et al., 2010; Schaller et al., 2012; Stoebner and Lant, 2014). Once crops are selected for any year, allocation rules concern a choice (1) of suitable cultivation area for each crop (all suitable plots for the considered crop), (2) of the crop surface area (total area of a considered crop on the farmland), (3) of crop return time (acceptable time to reseed the same crop on the same plot) and (4) of preceding-following crop pairs (acceptable temporal crop sequences) (Aubry et al., 1998). Describing these rules and identifying their drivers is necessary to explain the observed spatiotemporal patterns of crop location at the landscape scale (Schaller et al., 
2012). This is also a prerequisite both to simulate landscape patterns and to compel landscape evolution models (Thenail et al., 2009; Castellazzi et al., 2010; Houet et al., 2014; Jahel, 2016). As shown by most of the abovementioned studies, the driving factors of crop allocation rules are internal (e.g., farming system, characteristics of farm resources such as land or workforce) and/or external (e.g., market conditions, climate) on a farm.

Intra-farmland fragmentation, hereafter called farmland fragmentation, is a typical characteristic of cultivated landscapes (Demetriou, 2013) that can be an internal driver of crop allocation. Farmland fragmentation is defined as the intensity of the division of farmland into numerous small fields that are spatially dispersed. Several processes can explain farmland fragmentation, including field fragmentation and farm area distribution. In southern Mediterranean countries, farmland fragmentation has been favoured by privatization policies for collective lands (Ben Saad and Bourbouze, 2013), legal rules governing inheritance, urbanization and the development of other land uses (Jouve, 2001). The average farm area is small, and the dispersion of farm fields is very common in these countries. For instance, the records from 2004-2005 indicate that 54\% of Tunisian farms were smaller than 5 ha, corresponding to $11 \%$ of the total agricultural area, $43 \%$ were between 5 and 50 ha, corresponding to $55 \%$ of the total agricultural area, and only $3 \%$ were larger than 50 ha, corresponding to $34 \%$ of the total agricultural area (MARH, 2006). In terms of farmland fragmentation, $69 \%$ of the Tunisian farms smaller than 5 ha had only one field block, whereas $62 \%$ of the farms larger than 5 ha had two or more field blocks, where a field block is defined as a group of fields less than $500 \mathrm{~m}$ from each other.

Numerous studies have shown the impact of farmland fragmentation on crop management and location, as well as the consequences on the economics and environment of the farm. For farmers, farmland fragmentation may generate opportunities related to risk management or crop scheduling (Bentely, 1987; Markussen et al., 2016). However, farmland fragmentation also generates management constraints, such as (1) reduced efficiency of field machinery due to the small sizes and/or irregular shapes of the fields, or (2) excessive or differentiated farmstead-field distances. These opportunities and constraints impact crop locations and management at the farm scale (McCall, 1985; DeLisle, 1982; Deffontaines et al., 1995; Gonzalez et al., 2004; Morlon and Trouche, 2005; Thenail et al., 2009; Markussen et al., 2016). Consequently, farmland fragmentation impacts the economic (Latruffe and Piet, 2014; Gonzalez et al., 2004; Markussen et al., 2016) and environmental (Sklenicka, 2016) performance of farms. Farmland fragmentation also creates a context of geographical proximity, since each field managed by a farmer is likely to be surrounded by several fields that are managed by other farmers, which may generate neighbouring effects and interactions.

Neighbourhood interactions are a well-known driving factor of land use patterns (Verburg et al., 2004; Sidharthan and Bhat, 2014; Stoebner and Lant, 2014; Xiao et al., 2015; Anputhas et al., 2016) and correspond to the first law of geography (Tobler, 1970). Neighbourhood interactions reflect attraction or repulsion effects between land use types. For example, the high probability of a certain type of land use at a given place in the neighbourhood reflects an attraction effect. Attraction effects may be linked to (1) common driving factors such as soil type, microclimatic conditions, and land tenure arrangement, or (2) spatial processes that generate agglomeration benefits, such as learning through imitation and/or positive spillovers (Xiao et al., 2015; Anputhas et al., 2016; Sidharthan and Bhat, 2014; Stoebner and Lant, 2014). Repulsion effects may result from different needs in terms of biophysical conditions (e.g., soil/crops adequacy) or from damage caused by a land use type (e.g., damage to crops by rabbits, boars and birds from nearby forests). These neighbouring effects are commonly quantified in land use models based on grid data that refer to neighbouring pixels (Verburg et al., 2004). To the best of our knowledge, these effects are rarely quantified in models that consider the farm scale, and, if so, they refer to the centroids of neighbouring farms (Martinetti and Geniaux, 2016) and not the neighbouring fields.

Overall, existing studies have not addressed the impact of farmland fragmentation and the subsequent neighbouring interactions on crop allocation rules, whereas crop management is likely to be strongly driven by a combination of the two factors. Therefore, the current study aimed to explore how much farmland fragmentation can drive the decisions made by farmers about annual crop allocation by characterizing and quantifying the influences of both crop sequences and neighbouring crops at the 
field scale. We addressed this issue by considering an agricultural watershed located within the Cap Bon Peninsula in northeastern Tunisia.

\section{Materials and methods}

\subsection{Study area}

The study area was the Lebna watershed $\left(210 \mathrm{~km}^{2}, 36^{\circ} 43^{\prime} \mathrm{N}-36^{\circ} 53^{\prime} \mathrm{N} ; 10^{\circ} 40^{\prime} \mathrm{E}-10^{\circ} 58^{\prime} \mathrm{E}\right)$ located in the Nabeul Governorate on the Cap Bon Peninsula in northeastern Tunisia (Figure 1). The Lebna landscape includes three zones (upstream, intermediate and downstream) according to geomorphologic, geological and land cover-land use criteria (IAO, 2002). A continuous ecosystem gradient is observed along the upstream-downstream transect. The upstream part, ranging from $200 \mathrm{~m}$ a.s.l. to $637 \mathrm{~m}$ a.s.l., corresponds to the most abrupt gradient of the watershed. The intermediate zone, with altitudes ranging from $80 \mathrm{~m}$ a.s.l. to $200 \mathrm{~m}$ a.s.l., corresponds to the Lebna hills and includes a network of wadis (i.e., intermittent rivers). The downstream zone, with altitudes ranging from $0 \mathrm{~m}$ a.s.1. to $80 \mathrm{~m}$ a.s.l., includes the Lebna plain. The climate regime is at the boundary between subhumid and semiarid (IAO, 2002). From downstream to upstream, the mean annual rainfall and the mean annual evapotranspiration (Penman-Monteith reference crop) range from $450 \mathrm{~mm}$ to $800 \mathrm{~mm}$ and from 1000 to $1500 \mathrm{~mm}$, respectively (IAO, 2002; Zitouna-Chebbi et al., 2012). The Lebna watershed is subject to soil erosion and subsequent reservoir siltation (IAO, 2002; Gaubi et al., 2017). The diffuse erosion rate, which results from agricultural practices, is four times greater than the concentrated erosion rate (Ben Slimane et al., 2013; 2015).

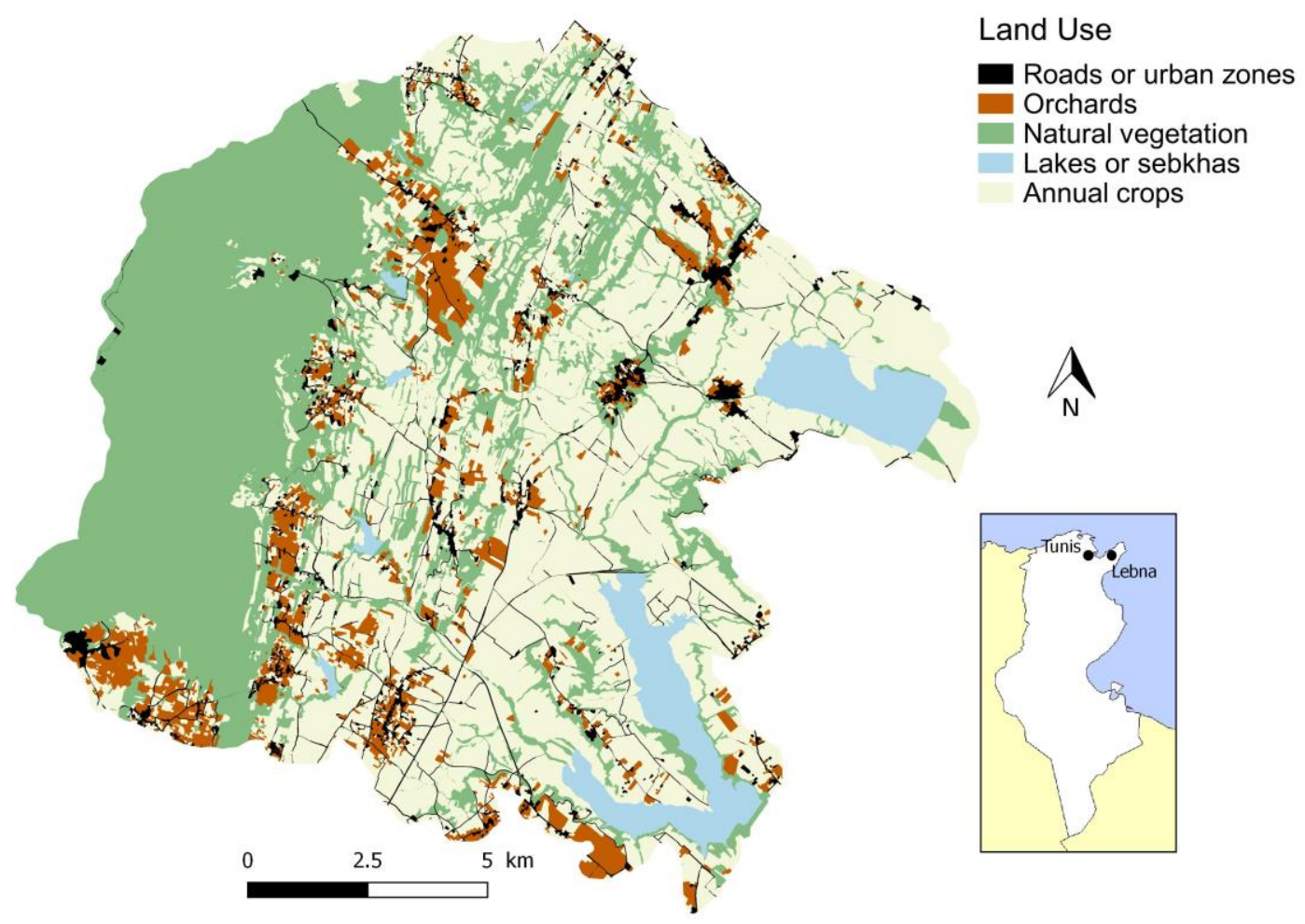

Figure 1. The study area. The map was obtained from manual digitization and classification of a Spot 6 image dated 03/21/2016 and a Google Earth image dated 05/24/2016.

One-third of the watershed area is covered by natural vegetation (Table 1). The natural vegetation areas include the steepest parts of the watershed, as well as the shores of the hill reservoirs, lakes and 
wadis. Arable lands are spread across $57 \%$ of the watershed area. Agricultural systems are mainly based on rainfed mixed farming and livestock. As in other rainfed agricultural systems in North Africa (Latiri et al., 2010), the Lebna agriculture mainly includes cereal production, although its climate increases the crop diversity. Annual crop areas spread over $49 \%$ of the watershed area. The annual crops include grain cereals (mainly wheat), fodder crops (mainly barley, oats and triticale), spices (mainly coriander) and legumes (mainly fava bean). Perennial crops (mainly olive trees) cover $8 \%$ of the total area of the watershed. Livestock husbandry includes cattle, sheep and goat breeding. Livestock feeding relies on farm production, natural vegetation, and external food supplements. There are three main forms of grazing: (1) grazing of fodder crops, (2) grazing of crop residues, and (3) grazing of natural vegetation. Animals can either be tethered to a stake or can graze freely under shepherd supervision.

Table 1: Cover of land use types and land use classes within the Lebna watershed. Percentages are given relative to the total watershed area.

\begin{tabular}{lll}
\hline Land use type & Land use class & Cover (\%) \\
\hline \multirow{2}{*}{ Natural and semi-natural areas } & $\begin{array}{l}\text { Forests, shrubs, herbaceous pastures, } \\
\text { outcrops of sandstone }\end{array}$ & 34 \\
\cline { 2 - 3 } & Artificial lakes, dam, sebkhas & 6 \\
\hline Sealed manmade areas & $\begin{array}{l}\text { Roads, dirt tracks, isolated houses, urban } \\
\text { areas }\end{array}$ & 3 \\
\hline \multirow{2}{*}{ Rainfed mixed farming } & Annual crops & 49 \\
\cline { 2 - 3 } & Perennial crops & 8 \\
\hline
\end{tabular}

Within the Lebna watershed, the cultivated landscape consists of a mosaic of very small agricultural fields, and the average field area is less than 1 ha. The Lebna watershed is a landscape of open fields; most fields are unfenced and cannot be directly accessed by roads. Due to the small farm sizes, most farmers have little equipment and therefore outsource mechanized operations to agricultural contractors. The crop cycles range from autumn to summer (Figure 2), and crop scheduling differs from one crop to another (Mekki et al., 2006). Cereals may be stereotypically rotated with legumes or spices to capture the benefits of nitrogen fixation (in the case of legumes) and/or to break pest or weed cycles.

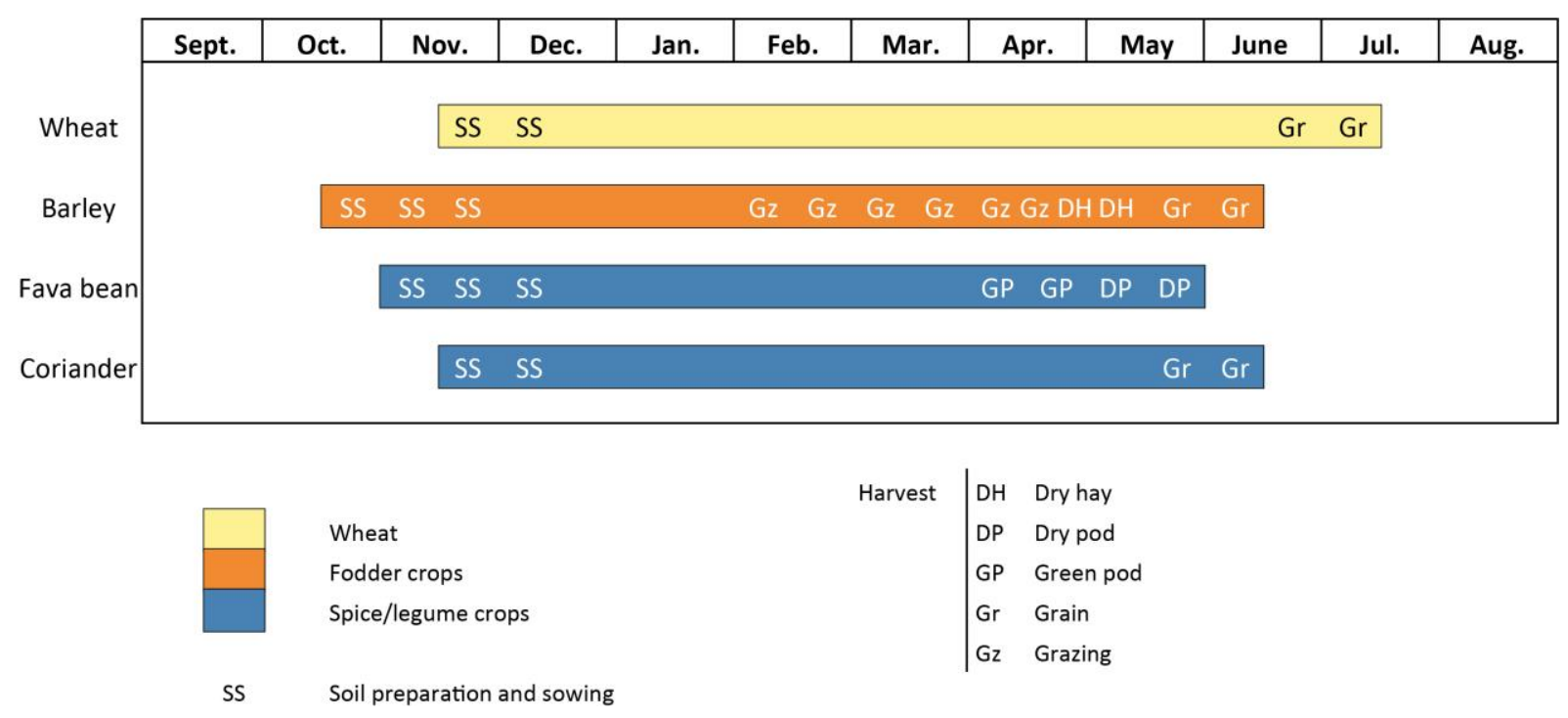

Figure 2. Main crop cycles and crop scheduling in the Lebna watershed. 


\subsection{Overview of the methodological strategy}

To evaluate any possible influence of farmland fragmentation on the decisions by farmers on annual crop allocation, we conducted a comparative analysis between isolated and non-isolated fields belonging to a sample of farms. Isolation/non-isolation was related to the spatial distribution of the fields belonging to a given farmer. A field was defined as an agricultural plot managed by a single farmer and with a single annual crop.

As shown in Figure 3, the methodological strategy included three steps. The data collection (Step 1) occurred during two successive annual crop cycles (2014-2015 and 2015-2016) within the fields of the selected farmers and within their neighbourhoods. After splitting the sample of the surveyed farmer fields (FFs) between isolated and non-isolated fields (Step 2), we used a two-stage procedure to compare the crop allocation rules used in each of the two subsamples (Step 3). First, we characterized the influences of crop sequences and neighbouring crops on the annual crop allocation. Second, we quantified the statistical significances of the relative influences of both crop sequences and neighbouring crops.

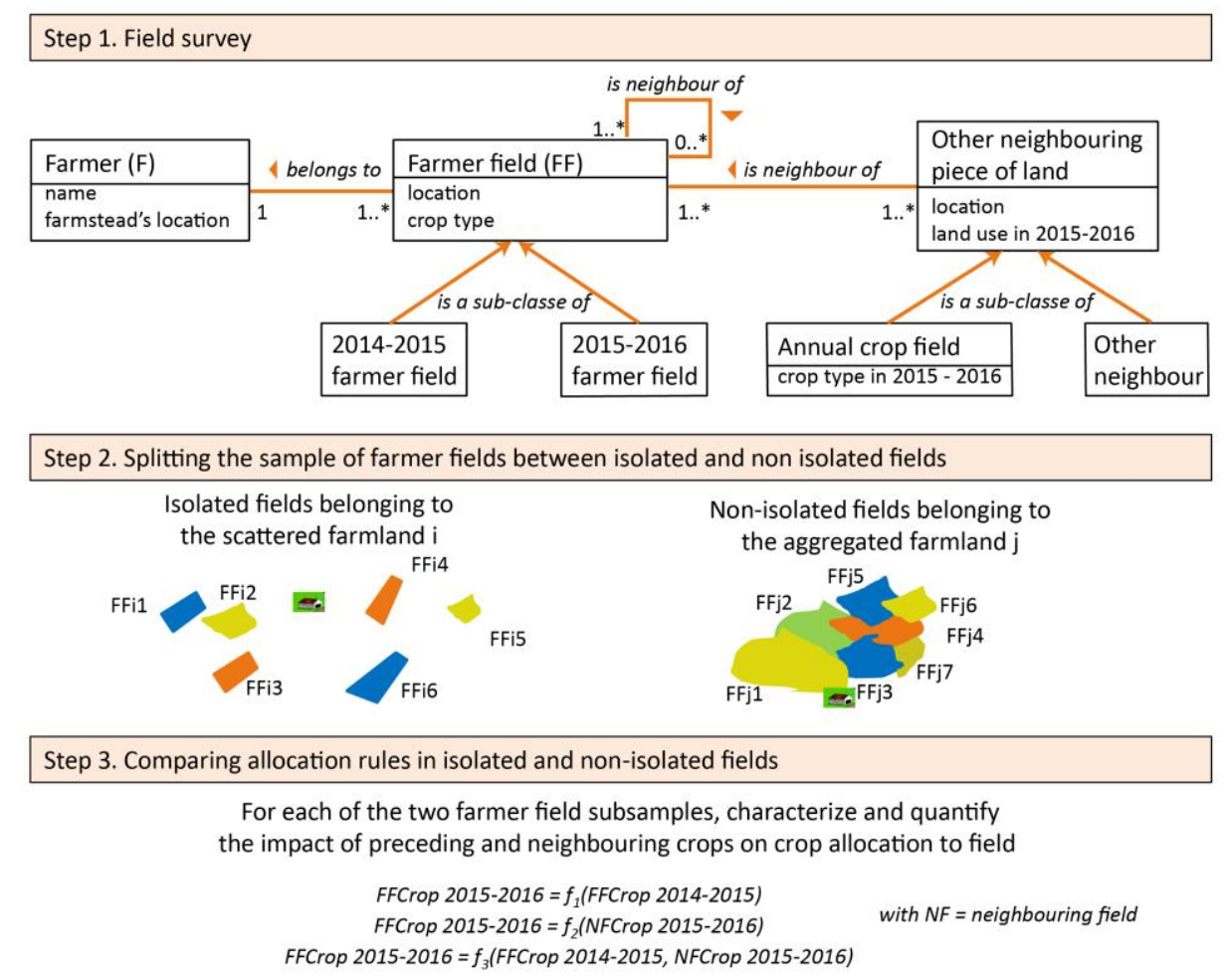

Figure 3. Methodological framework. Step 1 was described with a Unified Modelling Language (UML) class diagram.

\subsection{Geo-database of surveyed agricultural fields}

To characterize and quantify the influence of crop sequences on crop allocation, we conducted field surveys over two successive crop cycles (2014-2015 and 2015-2016) on 30 farms. The farms were selected to account for a diversity of size, level of farmland fragmentation and geographical location (spatial diversity of relief, soil and climate). The selected farms included 360 fields in 2014-2015 and 355 fields in 2015-2016 because of a common process of field aggregation/splitting from one year to another. These fields are hereafter called farmer fields (FFs). The field survey included the type of crop sown on the fields during the 2014-2015 and 2015-2016 crop cycles. We differentiated three main crop types according to their main agronomic characteristics and use: (1) wheat (always 
harvested as a cereal grain); (2) spice/legume crops (mainly used for human food, stereotypically rotated with wheat); and (3) fodder crops.

To characterize and quantify the influence of neighbouring crops on crop allocation, we conducted a complementary land use survey in the neighbourhoods of the FFs during the 2015-2016 crop cycle. This survey recorded the type of crop sown on 1220 fields distributed between the fields that were adjacent to the FFs, and some non-adjacent fields in the vicinity that were sown with annual crops (Figure 4). The farmers of these fields were unknown. The land use survey in the neighbourhood of the FFs also included the perennial crops and the natural or manmade elements of the land adjacent to the FFs. We accounted for the primary adjacent roads and dirt tracks that were wide enough to act as a barrier.

All of the FFs as well as the farmsteads were precisely geo-referenced and mapped (Figure 4) using a two-step procedure. The field boundaries were first geolocalized using Global Positioning System (GPS) routes (precision $\leq 5 \mathrm{~m}$ ). Second, the limits were redrawn using both a panchromatic Spot 6 image (precision $1.5 \mathrm{~m}$ ) dated 05/03/2015 for the 2014-2015 crop cycle and a panchromatic Spot 6 image (precision $1.5 \mathrm{~m}$ ) dated 03/21/2016 for the 2015-2016 crop cycle. The other field boundaries were digitized from the panchromatic Spot 6 image dated 03/21/2016.

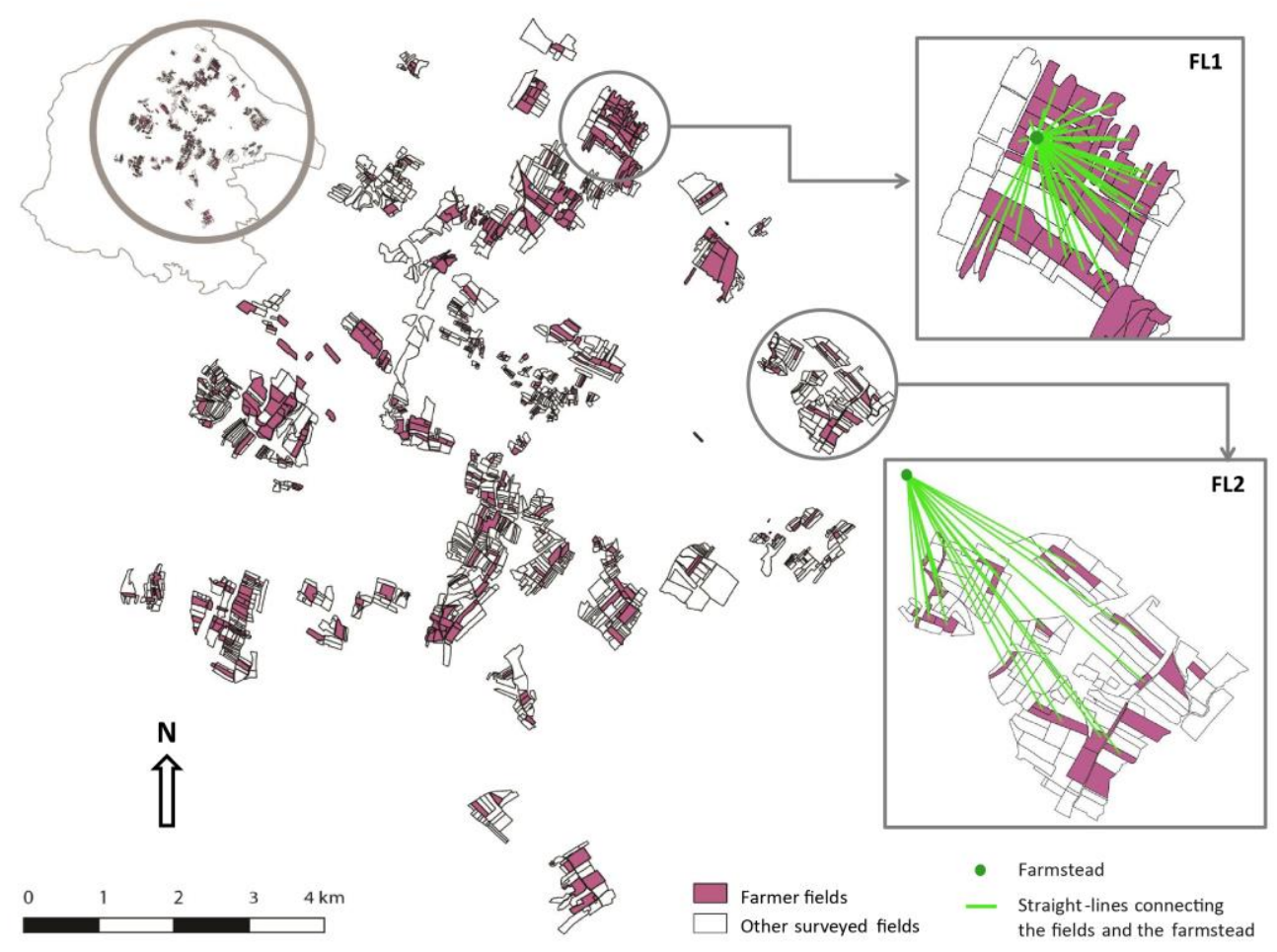

Figure 4. Location of the fields surveyed in the 2015-2016 crop cycle within the Lebna watershed and two typical farmlands (FL1 and FL2). FL1 is an aggregated farmland and FL2 is a scattered farmland.

\subsection{Data analysis}

\subsubsection{Splitting the dataset into isolated and non-isolated fields}

We assumed that for any FF, the annual crop allocation was driven by both (1) the relative importance of neighbouring fields outside the farm and (2) the farmstead-field distance. Non-isolated fields were defined as the fields located in a block of fields belonging to the same farm, with the nearest boundary of the block less than $300 \mathrm{~m}$ from the farmstead. Isolated fields were defined as fields that were 
(1) mainly surrounded by fields belonging to other farms, and (2) whose distance to the farmstead was greater than $300 \mathrm{~m}$.

As seen in Figures 3 and 4, two typical farmland structures were observed: (1) aggregated farmlands with fields mostly grouped around farmsteads, and (2) highly fragmented farmlands, including dispersed individual fields or small field islets. Beyond these main trends, we had to proceed with few field farms that depicted different characteristics. At the watershed extent, we observed that $4 \%$ of the fields were located in large blocks far from the farmstead, which were classified as isolated or nonisolated fields according to the accessibility of the field from the road. We also observed that $3 \%$ of the fields were located less than $300 \mathrm{~m}$ from the farmstead, and these fields were classified as isolated fields because they were not visible from the farmstead and their neighbours were mainly fields that did not belong to the same farmer.

\subsubsection{Characterizing the influences of crop sequences and neighbouring crops on crop allocation}

The influences of crop sequences and neighbouring crops were characterized for each of the two FF subsamples (isolated and non-isolated fields).

We assessed the influence of the preceding crop on the current crop by performing a Pearson chisquare test on a contingency table that crossed the crop types of the previous (2014-2015) and current (2015-2016) crop cycles. Since the field limits could be mismatched from one year to another because of field aggregation/splitting, we registered the preceding crop for a given field in 2015-2016 as the crop that dominantly covered the corresponding area in 2014-2015.

We next analysed the influence of neighbouring crops on the current crop in a given FF using the data collected for 2015-2016 and two complementary neighbourhood metrics. We successively considered neighbourhood as (1) a binary property when two fields share a boundary (adjacent neighbours), and (2) a continuous distance between field centroids.

For the binary neighbourhood metric, the influence of the neighbourhood on crop $i$ in the FFs (with $i$ being [wheat, spices/legumes, fodder crops]) was explored as follows: we successively calculated the fraction $y$ of the FFs with crop $i$ having at least $\mathrm{x} \%$ of adjacent neighbours with the same crop $i$, and we constructed the resulting distribution curves $f y=f(x)$ for $x$, ranging from 5 to 100 , at a 2.5 step.

For continuous neighbourhood metric, the influence of neighbourhood on a crop $i$ was explored as a function of the distance $h$ between fields centroids (including adjacent neighbours but not only) using a spatial indicator correlogram (Webster and Oliver, 2001) as expressed in Equation 1. The correlogram was computed here from all field pairs including at least one of the FFs, as follows:

$$
\rho_{i}(h)=\frac{1}{n_{h}} \frac{\sum_{\left(s_{\alpha}, s_{\beta}\right) / s_{\alpha} \in i}(1-\bar{i})\left(\mathbb{1}_{i}\left(s_{\beta}\right)-\bar{i}\right)}{\operatorname{var}\left(\mathbb{1}_{i}(s)\right)}
$$

(Equation 1)

where $\rho_{i}(h)$ denotes the spatial autocorrelation for crop $i$ at the lag distance $h$ expressed in metres; $S_{\alpha}$ and $S_{\beta}$ are two fields where $S_{\alpha}$ is cropped with $i$ and the $\left(S_{\alpha}, S_{\beta}\right)$ distance equals $h ; n_{h}$ denotes the total number of field pairs at distance lag $h ; \bar{i}$ denotes the overall proportion of crop $i ; \mathbb{1}_{i}\left(s_{B}\right)=1$ if $S_{\beta}$ is cropped with $i$ and is zero otherwise; $S$ denotes any parcel in the population; and $\mathbb{1}_{i}(S)=1$ if $S$ is cropped with $i$ and is zero otherwise.

For both metrics, we tested the significance of the results by comparing them to a spatially random distribution of neighbouring crops. For that purpose, spatial Mantel tests (Legendre, 2000) consisting of crop value permutations on neighbouring fields in respect to the overall crop distributions and field locations (Figure 5) were performed. The 95 and 99\% confidence bands of the Mantel test were built in both cases from 1000 permutations. 


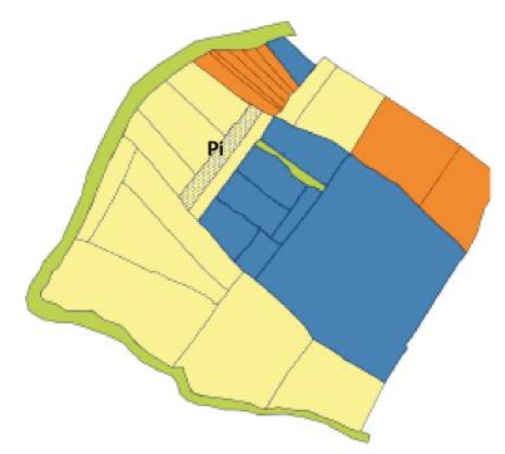

Observed distribution

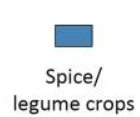

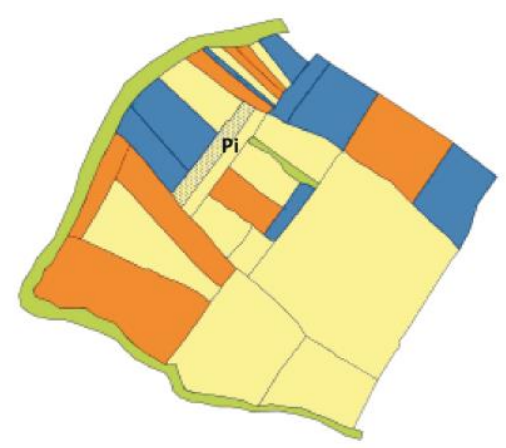

Random distribution a

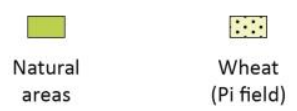

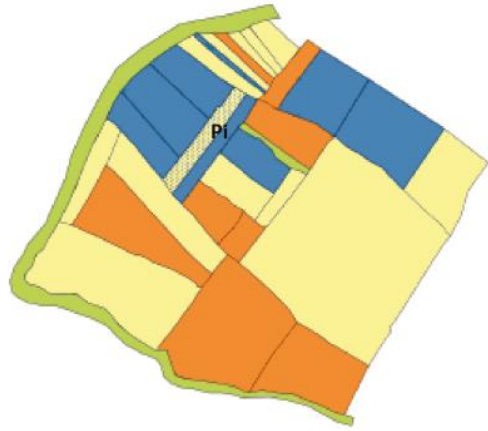

Random distribution b

Figure 5. The observed and randomly permutated crops around wheat field $P i$ in a zoom area with 29 fields. The number of fields for a given crop type is constant for the observed distribution and the two random distributions. In the observed distribution, the neighbouring wheat fields represented $83 \%$ of the land use pieces adjacent to $P i$; but they represented only 33\% in both random permutations $a$ and $b$.

\subsubsection{Quantifying the relative influences of crop sequences and neighbouring crops on crop allocation}

Linear discriminant analysis was applied independently to the isolated and the non-isolated fields, which allowed for the quantification of the respective weights of the "preceding crop" and three variables describing the adjacent crops on the crop allocation in the fields. These three variables were the fractions (relative to all adjacent neighbours) of wheat fields, spice/legume fields and fodder fields.

Three prediction models were developed from the preceding crop variable, the adjacent crop variables, and the entire set of variables. The models were calibrated over a stratified field subset, including twothirds of the total sample of isolated or non-isolated FFs, with a random selection that represented the observed fractions of the crop types over the entire sample. Then, for each model, the overall accuracy was computed over a validation subsample that included the remaining fields. The procedure was repeated 1000 times, and the results were averaged. Finally, the prediction rate of each model was compared to the prediction obtained from 1000 random crop distributions. We used Student's t-tests to assess the significances of the observed differences in the prediction rates.

\section{Results}

\subsection{Diversity of crops and farmland characteristics in the surveyed farms}

The cultivated area per farm ranged from 0.9 to 28.2 ha during the 2015-2016 crop cycle (Table 2). On average, annual crops represented $92 \%$ of the total cultivated area and were almost equally distributed among the three types of crop. The remaining area included orchards (7\% of the cultivable area) and fallow $(1 \%)$. No relationship was observed at the farm scale between the total cultivable area and the distribution of crops.

Table 2: Distribution of crops in the surveyed farms for the 2015-2016 crop cycle.

\begin{tabular}{|c|c|c|c|c|c|c|c|c|}
\hline \multirow[b]{3}{*}{ Farmer } & \multirow{3}{*}{$\begin{array}{l}\text { Cultivable } \\
\text { area (ha) }\end{array}$} & \multicolumn{7}{|c|}{$\%$ of the cultivable area } \\
\hline & & \multicolumn{4}{|c|}{ Annual crops } & \multicolumn{3}{|l|}{ Others } \\
\hline & & Wheat & $\begin{array}{l}\text { Spices and } \\
\text { legumes }\end{array}$ & $\begin{array}{l}\text { Fodder } \\
\text { crops }\end{array}$ & $\begin{array}{l}\text { Total } \\
\text { annual } \\
\text { crops }\end{array}$ & $\begin{array}{l}\text { Arbori- } \\
\text { culture }\end{array}$ & Fallow & Total other \\
\hline E01 & 7.5 & 32 & 30 & 26 & 87 & 13 & 0 & 13 \\
\hline E02 & 26.6 & 20 & 13 & 55 & 89 & 11 & 0 & 11 \\
\hline E13 & 1.4 & 37 & 61 & 0 & 98 & 2 & 0 & 2 \\
\hline E25 & 15.0 & 57 & 17 & 25 & 100 & 0 & 0 & 0 \\
\hline
\end{tabular}




\begin{tabular}{lllllllll} 
E28 & 17.1 & 0 & 21 & 78 & 99 & 0 & 1 & 1 \\
E03 & 22.4 & 35 & 29 & 34 & 99 & 1 & 0 & 1 \\
E04 & 3.4 & 0 & 35 & 53 & 88 & 0 & 12 & 12 \\
E05 & 9.4 & 37 & 46 & 16 & 98 & 0 & 2 & 2 \\
E07 & 28.2 & 40 & 15 & 45 & 100 & 0 & 0 & 0 \\
E10 & 18.3 & 9 & 18 & 14 & 41 & 41 & 18 & 59 \\
E14 & 18.4 & 11 & 19 & 64 & 94 & 6 & 0 & 6 \\
E15 & 12.5 & 60 & 37 & 0 & 97 & 3 & 0 & 3 \\
E06 & 2.5 & 54 & 32 & 13 & 100 & 0 & 0 & 16 \\
E08 & 11.8 & 22 & 28 & 34 & 84 & 16 & 0 & 20 \\
E09 & 10.2 & 37 & 35 & 8 & 80 & 20 & 0 & 0 \\
E11 & 5.3 & 38 & 28 & 33 & 100 & 0 & 0 & 6 \\
E12 & 18.6 & 36 & 29 & 29 & 94 & 4 & 2 & 0 \\
E16 & 13.1 & 43 & 46 & 10 & 100 & 0 & 0 & 46 \\
E17 & 7.6 & 0 & 17 & 36 & 54 & 46 & 0 & 3 \\
E18 & 11.7 & 19 & 12 & 66 & 97 & 0 & 3 & 0 \\
E19 & 2.1 & 38 & 0 & 44 & 82 & 18 & 0 & 0 \\
E20 & 22.9 & 53 & 36 & 12 & 100 & 0 & 0 & 0 \\
E21 & 17.5 & 19 & 69 & 12 & 100 & 0 & 0 & 0 \\
E22 & 0.9 & 47 & 0 & 53 & 100 & 0 & 0 & 0 \\
E23 & 1.8 & 78 & 0 & 22 & 100 & 0 & 0 & 0 \\
E24 & 4.4 & 17 & 60 & 23 & 100 & 0 & 0 & 0 \\
E26 & 4.3 & 62 & 38 & 0 & 100 & 0 & 0 & 0 \\
E27 & 2.8 & 0 & 100 & 0 & 100 & 0 & 0 & 0 \\
E29 & 2.4 & 31 & 64 & 5 & 100 & 0 & 0 & 0 \\
E30 & 21.8 & 39 & 40 & 18 & 96 & 4 & 0 & 1 \\
\hline Whole & 342.0 & 31 & 30 & 31 & 92 & 7 & & 0 \\
sample & 34 & & & & & & & \\
\hline
\end{tabular}

A seen in Table 3, in 2015-2016, 239 FFs were considered isolated, and 116 were non-isolated. 12 farms were considered totally or partially aggregated with few isolated fields, and 18 were considered non-aggregated with several isolated fields. On average, isolated fields were characterized by a smaller area $(0.73 \mathrm{ha})$ and a larger farmstead-field distance $(1210 \mathrm{~m})$ than non-isolated fields $(1.2 \mathrm{ha}, 320 \mathrm{~m})$.

Table 3: Distribution of isolated and non-isolated annual crop fields on the surveyed farms for the 2015-2016 crop cycle.

\begin{tabular}{|c|c|c|c|c|c|c|c|c|c|}
\hline \multirow[b]{2}{*}{ Farmer } & \multirow[b]{2}{*}{ Type of farmland } & \multicolumn{3}{|c|}{ Isolated fields } & \multirow[b]{2}{*}{$\begin{array}{l}\text { Total } \\
\text { isolated } \\
\text { area (ha) }\end{array}$} & \multicolumn{3}{|c|}{ Non-isolated fields } & \multirow[b]{2}{*}{$\begin{array}{l}\text { Total } \\
\text { aggregated } \\
\text { area (ha) }\end{array}$} \\
\hline & & Number & $\begin{array}{l}\text { Mean } \\
\text { area } \\
\text { (ha) }\end{array}$ & $\begin{array}{l}\text { Mean } \\
\text { FFD } \\
(\mathrm{km}) \\
\end{array}$ & & Number & $\begin{array}{l}\text { Mean } \\
\text { area } \\
\text { (ha) }\end{array}$ & $\begin{array}{l}\text { Mean } \\
\text { FFD } \\
(\mathrm{km})\end{array}$ & \\
\hline E01 & aggregated & 0 & - & - & 0 & 9 & 0.7 & 0.1 & 6.5 \\
\hline E02 & aggregated & 0 & - & - & 0 & 35 & 0.7 & 0.3 & 23.5 \\
\hline E13 & aggregated & 0 & - & - & 0 & 4 & 0.3 & 0.1 & 1.3 \\
\hline E25 & aggregated & 0 & - & - & 0 & 16 & 0.9 & 0.3 & 15.0 \\
\hline E28 & aggregated & 0 & - & - & 0 & 5 & 3.4 & 0.5 & 16.8 \\
\hline E03 & partially aggregated & 1 & 1.2 & 2.1 & 1.2 & 14 & 1.5 & 0.3 & 20.9 \\
\hline E04 & partially aggregated & 1 & 0.6 & 1 & 0.6 & 5 & 0.5 & 0.2 & 2.4 \\
\hline E05 & partially aggregated & 2 & 1.8 & 0.8 & 3.6 & 5 & 1.1 & 0.2 & 5.7 \\
\hline E07 & partially aggregated & 4 & 1.4 & 1.5 & 5.5 & 6 & 3.8 & 0.2 & 22.7 \\
\hline E10 & partially aggregated & 4 & 0.8 & 0.5 & 3.1 & 5 & 0.9 & 0.4 & 4.3 \\
\hline E14 & partially aggregated & 5 & 0.9 & 1.3 & 4.7 & 7 & 1.8 & 0.4 & 12.5 \\
\hline E15 & partially aggregated & 4 & 1.3 & 1 & 5.0 & 5 & 1.4 & 0.9 & 7.1 \\
\hline E06 & scattered & 6 & 0.4 & 0.3 & 2.5 & 0 & - & - & 0 \\
\hline E08 & scattered & 21 & 0.5 & 2.3 & 9.9 & 0 & - & - & 0 \\
\hline E09 & scattered & 15 & 0.5 & 1 & 8.2 & 0 & - & - & 0 \\
\hline E11 & scattered & 8 & 0.7 & 1 & 5.3 & 0 & - & - & 0 \\
\hline E12 & scattered & 24 & 0.7 & 0.8 & 17.6 & 0 & - & - & 0 \\
\hline E16 & scattered & 21 & 0.6 & 1.2 & 13.0 & 0 & - & - & 0 \\
\hline E17 & scattered & 10 & 0.4 & 2.3 & 4.1 & 0 & - & - & 0 \\
\hline E18 & scattered & 11 & 1 & 1.2 & 11.4 & 0 & - & - & 0 \\
\hline E19 & scattered & 6 & 0.3 & 1.3 & 1.7 & 0 & - & - & 0 \\
\hline E20 & scattered & 9 & 2.5 & 1.6 & 22.9 & 0 & - & - & 0 \\
\hline E21 & scattered & 14 & 1.6 & 0.8 & 17.5 & 0 & - & - & 0 \\
\hline
\end{tabular}




\begin{tabular}{llllllllll} 
E22 & scattered & 3 & 0.3 & 0.6 & 0.9 & 0 & - & - & 0 \\
E23 & scattered & 3 & 0.6 & 1.5 & 1.8 & 0 & - & - & 0 \\
E24 & scattered & 7 & 0.6 & 1.1 & 4.4 & 0 & - & - & 0 \\
E26 & scattered & 5 & 0.9 & 1.2 & 4.2 & 0 & - & - & 0 \\
E27 & scattered & 2 & 1.4 & 1.5 & 2.8 & 0 & - & - & 0 \\
E29 & scattered & 15 & 0.2 & 0.9 & 2.4 & 0 & - & - & 0 \\
E30 & scattered & 38 & 0.6 & 1.1 & 21.0 & 0 & - & - & 0 \\
\hline Whole & 239 & 0.7 & 1.2 & 175.5 & 116 & 1.2 & 0.3 & 138.8 \\
sample & & & & & & & & \\
\hline
\end{tabular}

Note: FFD is the farmstead-field distance

\subsection{Effect of the preceding crop on crop distribution}

The results of the distribution of crops in a FF in accordance with the preceding crop are depicted in Figure 6. The figure shows that regardless of field context (i.e., isolated or non-isolated), wheat as a preceding crop was positively associated with spices/legumes as a following crop, and vice versa. Fodder crops were positively associated with fodder crops. In the case of isolated fields, both "wheatwheat" and "spices/legumes - spices/legumes" pairs were significantly underrepresented.

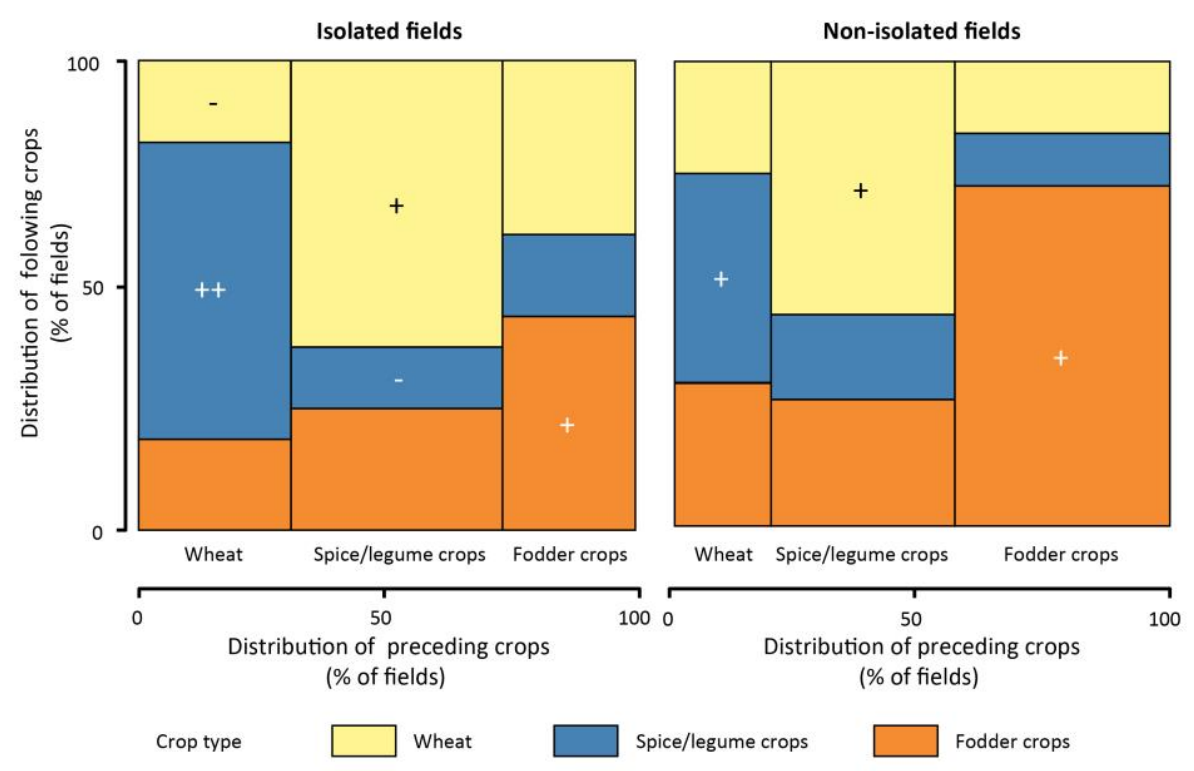

Figure 6. Mosaic plot representing the distribution of crops in farmer fields depending on the preceding crop. The independence between the modalities of the previous and current crops according to a Pearson chi-square test is indicated as follows: "+" and "++" indicate a strong and very strong positive dependency, respectively; "-"” indicates a strong negative dependency.

\subsection{Effect of neighbouring crops on crop distribution}

Figure 7 presents the distribution curves of each crop type on the FFs according to the occurrence of the same crop type in the adjacent neighbourhoods (binary neighbourhood metric exploration). For any crop $i$, a distribution curve above the $95-99 \%$ confident bands indicates that this crop is significantly more surrounded by the same crop than by other crops (attraction effect). Conversely, a distribution curve under the 95-99\% confident bands indicates a repulsion effect. A distribution curve within the confidence band indicates that the distribution of crop $i$ does not depend upon the adjacency of the same crop. Consequently, Figure 7 clearly shows significant differences between isolated and non-isolated fields. In isolated fields, wheat was surrounded much more by wheat than by other crops. Similarly, spice/legume crops were surrounded much more by spice/legume crops than by other crops. FFs with fodder crops were sown independently from the adjacent fodder crops. In non-isolated fields, the distribution of crops was independent of the distribution of adjacent crops. 

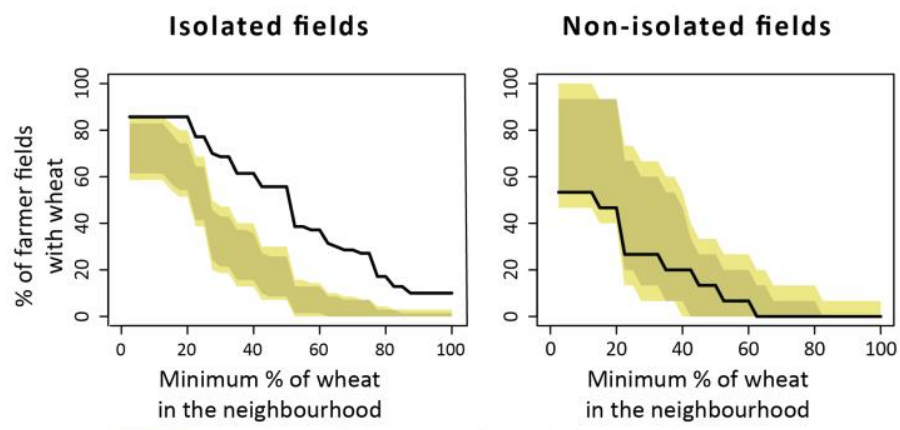

[1]-99\% confidence band for neighbouring wheat
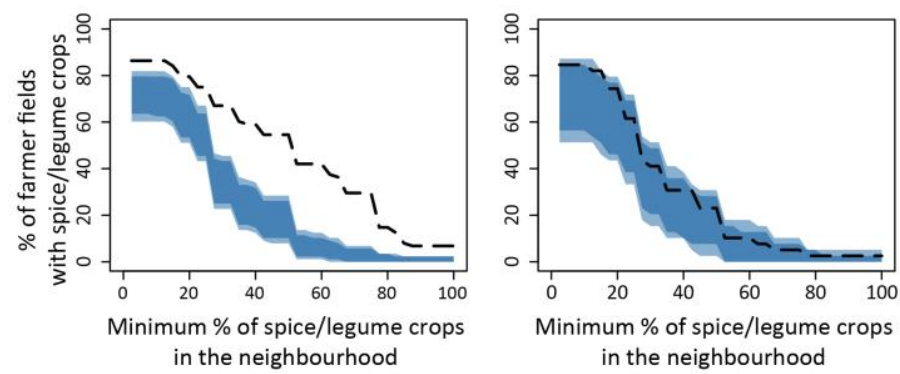

- $95-99 \%$ confidence band for neighbouring spice/legume crops
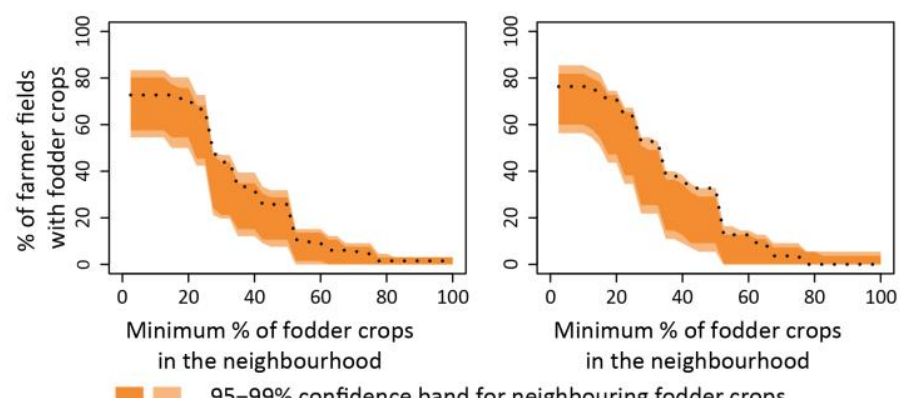

Figure 7. Distribution of crops on farmer fields as a function of crops on adjacent pieces of land, in accordance with the field context. For example, for $80 \%$ of isolated wheat fields, at least $20 \%$ of the adjacent land consisted of wheat fields.

The differences highlighted in Figure 7 are confirmed by the correlograms presented in Figure 8 (continuous neighbourhood metric exploration). The closer the correlation at a given distance is to one, the more frequent two fields at this distance depict the same crop $i$, which corresponds to an attraction effect at this distance. Conversely, negative and null correlations mean the two fields at this distance depict different crops (repulsion effect) and random crop associations (random effect), respectively. In addition, this continuous neighbourhood metric allows for crop patterns to be inferred: a progressive decrease in the correlogram (as for wheat in isolated fields, see Figure 8) indicates a patchy pattern for crop $i$ with the average patch diameter corresponding to the range of the correlogram. The range corresponds to the minimum distance where the correlation values fall within the $95 \%$ confidence band. However, when there is a significant correlation at a long distance (as for wheat in isolated fields at $800 \mathrm{~m}$, see Figure 8), it is not interpreted: the small numbers of field pairs at high distances results in the high dispersion of the correlation computation.

The correlation values in isolated fields shown in Figure 8 indicate a significant attraction effect between wheat fields separated by less than $300 \mathrm{~m}$, whereas the distribution of wheat fields was random at distances greater than $300 \mathrm{~m}$. An attraction effect between spice/legume fields also existed up to a distance of $600 \mathrm{~m}$ between fields, although the attraction was less clear. For fodder crops, the 
attraction effect was visible at very short distances, and the distribution was random at distances greater than $150 \mathrm{~m}$. For non-isolated fields, we observed short-distance repulsion effects or the random distribution of crops.
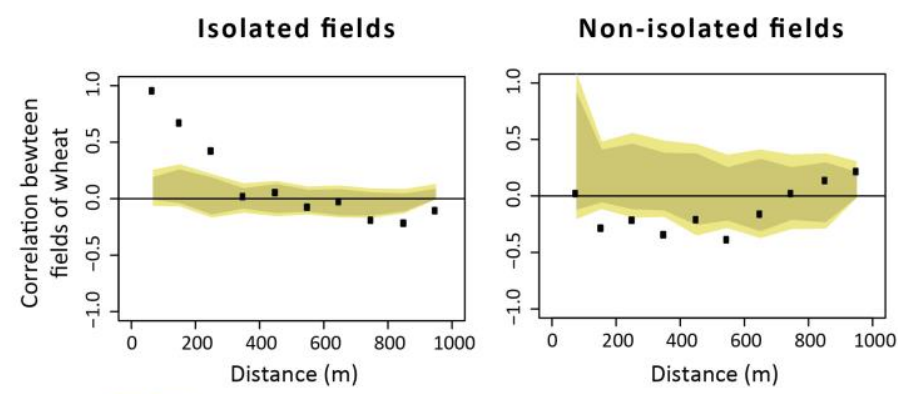

[D- $95 \%$ confidence band for wheat
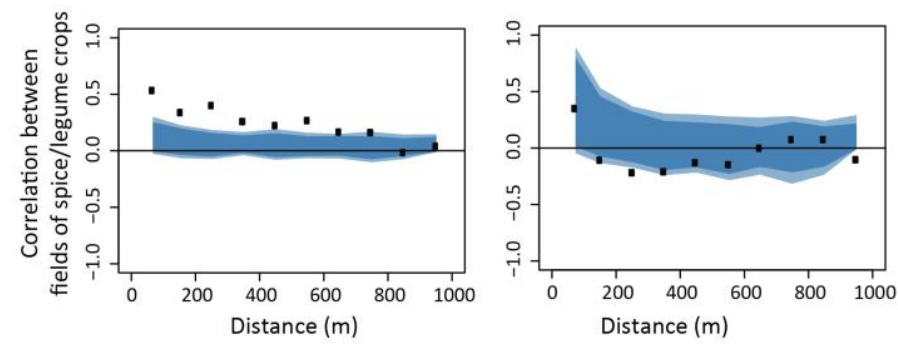

95-99\% confidence band for spice/legume crops
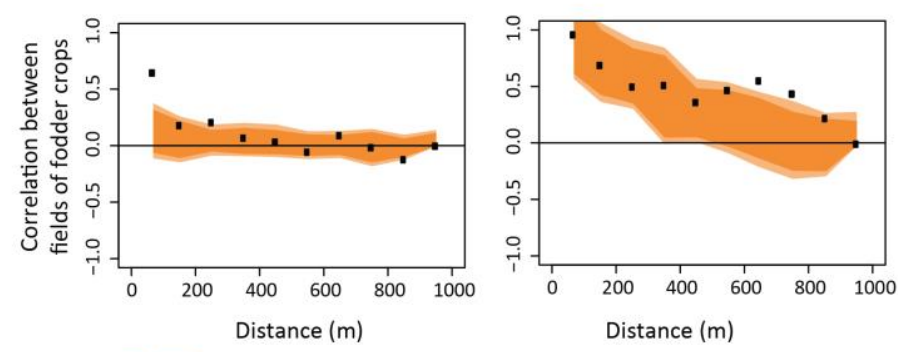

- 95-99\% confidence band for fodder crops

Figure 8. Correlogram for each type of crop in accordance with the field context.

\subsection{Weight of preceding and neighbouring crops in predicting the allocation of crops to fields}

Figure 9 shows the ability to predict crops in FFs from the "preceding crop" variable and the three variables describing the "adjacent crops". The results indicate that regardless of field context, the explanatory variables significantly improved the prediction of crop types compared to a random distribution. However, the weight of each set of variables tested depended upon the field context. For isolated fields, neighbouring crops and preceding crops had the same weight on crop choice. In nonisolated fields, crop choice depended significantly more on the preceding crop than on the neighbouring crops. In both isolated and non-isolated fields, the use of the entire set of variables permitted us to correctly predict the crops on approximately $60 \%$ of the fields. 

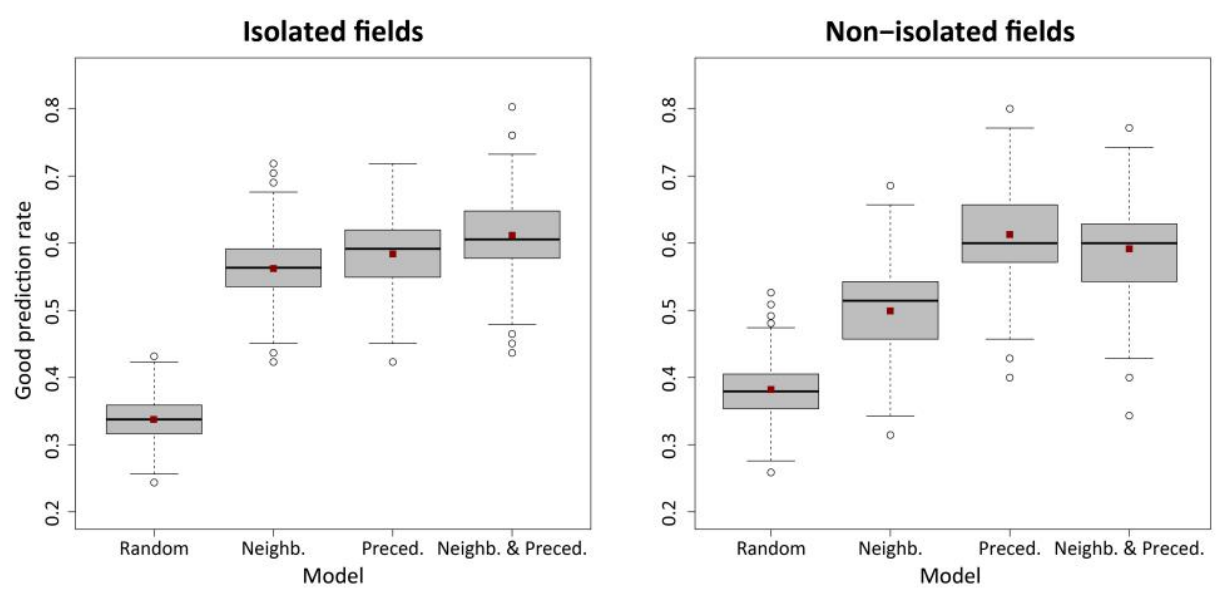

Figure 9. Boxplots of good prediction rates obtained from a random distribution of crops and three predictive models of isolated and non-isolated fields. Random: random distribution; Neighb: model based on the variables describing the adjacent crop types; Preced: model based on the "preceding crop" variable; Neighb. \& Preced: model based on the adjacent and preceding crops variables. The horizontal lines within the boxes represent the median values, and the square dots represent the mean values.

\section{Discussion}

\subsection{Variability of rules for crop allocation according to the field context}

In this study, we inferred statistical rules for crop allocation in accordance with the field context, i.e., isolated and non-isolated fields, that depended upon farmland fragmentation and field dispersion relative to the FFs and the farmstead. For each field context, the rules were defined from a statistical analysis that involved two potential allocation factors: (1) the main preceding crop and (2) the crop distribution in the neighbourhoods of the FFs. In both isolated and non-isolated fields, the preceding crop significantly influenced crop choice, whereas major differences in crop location were observed according to the neighbourhood. In isolated fields, the allocations of wheat and spice/legume crops significantly depended on the neighbourhood, and attraction effects were observed at short distances. In non-isolated fields, the distribution of crops according to neighbouring crops was more random.

We were able to analyse the observed results using informal farmer interviews during the field survey. When farm fields are aggregated around the farmstead, the farmers can establish their own crop allocation strategy. Then, the allocation constraints are mainly related to the cropping systems, with a strong impact from crop sequences. When farm fields are dispersed far from the farmstead, are not visible from the farmstead and are surrounded by fields belonging to other farms, the farmers must establish a crop allocation strategy in accordance with the ongoing strategies of the neighbouring fields. This strategy permits the management of three main constraints related to crop location. First, most of the fields are not directly accessible by a road or dirt track, and the farmers have to cross other fields to access them. In such cases, particularly for mechanized operations, it is necessary to synchronize the schedule of agricultural operations between fields. Second, synchronization is also necessary to avoid animal-related damage on fields that have not yet been harvested. Animal-related damage is related to the free grazing of fodder crops or crop residues in adjacent harvested fields because shepherd supervision is not always effective. Third, most farmers outsource mechanized operations, such as tillage and the harvest of cereals or fodder, to agricultural contractors. Synchronizing these operations between neighbouring fields simplifies the outsourcing.

Combined with these constraints, the characteristics of the different crops in terms of cropping calendar and location in the crop rotation explain why, according to our results (Figures 7 and 8), the attraction effects between fields with the same crop type are mainly concerned with wheat on the one hand, and with spices/legumes on the other hand. As seen in Figure 2, wheat is the last crop to be harvested in the area. This characteristic leads farmers to favour the clustering of wheat fields. In most 
cases, wheat succeeds spices/legumes (Figure 6), which in turn leads to the regrouping of spice/legume fields to prepare for wheat sowing the following year. According to the interviewed farmers, regrouping spices and legumes is possible despite the different harvesting dates because these crops are manually harvested and because coriander, which is harvested later than the other crops within this group, does not attract animals.

The absence of a significant impact from the type of neighbouring crops in terms of the spatial distribution of fodder crops (Figures 7 and 8) may also be explained by the proper characteristics of this group of crops. The harvesting period (from February to June) depends on the type of fodder produced: grazed fodder, dry hay or grain (Figure 2). Therefore, according to the interviewed farmers, different locations in space and the succession of crops are possible for fodder crops. When devoted to grazing, they are mainly cultivated as a monoculture (i.e., with fodder crops succeeding fodder crops) in areas located near the farmsteads or in areas characterized by shallow soil or sloping land that are dedicated to fodder production. When devoted to dry hay production, fodder crops may also be located close to fields of spices/legumes that have more or less the same harvesting dates and are used as a preceding crop for wheat. When devoted to grain production, fodder crops may be used as a preceding crop for spices/legumes and will be sown close to wheat areas. The declarations by farmers concerning the location of fodder crops in the succession of crops were corroborated by our results in terms of crop sequences for the 2014-2015 and 2015-2016 crop cycles (Figure 6). Fodder crops preferentially followed fodder crops, but they also preceded or followed wheat and spices/legumes.

This analysis echoes the observations or hypotheses made by agronomists, geographers and historians that have been used to explain the collective cropping plans that were characteristic of the open field landscapes in Europe for more than one thousand years (Caput, 1956; Watteaux, 2005; Calvo-Iglesias et al., 2009; Renes, 2010; Leturcq, 2014) or were still observed in the twentieth century or in the beginning of the twenty-first century in some regions of the world, such as the Serer region in Senegal (Pelissier P., 1953) or the Peruvian Andes (Hervé et al., 2002). Fragmented farms, unclosed plots, lowdensity path networks, and free pasturing on fallows and stubbles after harvest are regularly presented in the aforementioned studies to explain the division of arable lands in different areas, within which farmers had individual fields. Each year, each area was allocated to one of the crops (or types of crop) of the rotation or fallow when fallow was still practised.

\subsection{Remaining unexplained variability}

The explanatory variables that were addressed in the current study could explain a large part of the observed variability in crop allocation at the field scale. Nevertheless, $40 \%$ of the variability remained unexplained. We must further explore other variables that were reported as potential drivers in previous studies (e.g., Joannon et al. 2008; Thenail et al. 2009; Morlon and Benoit, 1990).

In particular, we should further test several variables that reflect the variability of biophysical conditions at the field scale, such as slope or soil characteristics (e.g., texture, depth, available water capacity). Slope can be calculated from available digital elevation models (DEMs), with some precautions regarding border effects and DEM resolution (Schoorl et al. 2000). The evaluation of soil characteristics is currently difficult because of the lack of data at an appropriate scale. The resolution of the available soil maps (IAO, 2002) is too coarse (1/50000) relative to the mean size of the fields (< $1 \mathrm{ha})$, whereas the available data on soil available water capacity must still be spatially extrapolated and mapped.

Moreover, interest should be paid to the variables that will allow for the better characterization of the field context. In this study, the field context was restricted to a characterization of the field location relative to the other farm fields and the farmstead. Our results suggest the need to precisely describe for each field (1) the accessibility, (2) the existence of linear elements (cactus hedge, ditches, banks, etc.) that mark a limit between adjacent fields and permit field protection against possible damage from herds and (3) the visibility from the farmstead. In the near future, thanks to the development of techniques for acquiring and processing very high spatial resolution satellite images (Fauvel et al., 2013; Sofia et al., 2016), the automated acquisition of path networks and other linear elements might 
be possible and would help define a more precise field context indicator. Visibility from the farmstead could be evaluated with digital surface models (DSM) that incorporate the heights of the elements above the terrain (Floriani and Magillo, 2003).

At the farm level, the impacts of production strategies and farmer resources on crop locations remain to be assessed. In particular, attention should be paid to the different uses of fodder crops and their relations with livestock. However, our results indicate that in the context of land fragmentation, the farm scale may not be sufficient to understand farmer decision-making. As noted by Morlon and Trouche (2005), there is a need to account for the relationships between neighbouring farmers. Existing differences between isolated and non-isolated agricultural fields and declarations of the interviewed farmers suggest that in the Lebna watershed, crop aggregates are not managed at the village scale. This finding is contrary to what has been observed in areas such as the Peruvian Andes (Hervé et al., 2002) or Senegal (Pelissier, 1955) or to what is commonly accepted as the typical management of the ancient open fields in Europe (Watteaux, 2005; Calvo-Iglesias et al., 2009; Renes, 2010; Leturcq, 2014). In the Lebna watershed, crop aggregates concern groups of farmers who exploit the same zones regardless of their places of residence. Therefore, defining the limits and understanding the functioning of these groups is a necessity to improve our understanding of the factors driving crop allocation.

\subsection{Towards characterization of spatiotemporal patterns of crop allocation at the watershed scale}

The extrapolation of our results would require validation over time (several successive years) and space (at the watershed scale). For this, remote sensing is a powerful tool that can be used to describe the patterns of crop distributions at the landscape scale and allows for the quantification of their variability in time and space. Remote sensing techniques are now able to provide times series data on the land use patterns of small farm landscapes (Inglada et al., 2015). The combined use of remote sensing data and data collected from field observations and interviews with farmers will allow for future improvements to our characterization and understanding of both farmer strategy for crop allocation and spatiotemporal patterns of land use.

\section{Conclusions}

Our study revealed the significant effect of farmland fragmentation on farmer decision-making for crop allocation within a northern Tunisian rainfed watershed that is dominated by annual fragmented cropland. When fields are dispersed, farmers implement, with some of their neighbours, collective rules of crop allocation that permit the management of common constraints. At the landscape scale, the consequence is the presence of field aggregates with the same crop type.

These results indicate that to improve our understanding of the drivers of crop allocation at the landscape level, it is not sufficient to only address the rules and drivers at the field and farm scales, but it is also necessary to account for the collective contexts in which farmers operate. Thus, our findings underline the need to deepen our knowledge of the existing agreements between farmers to refine our understanding of crop allocation.

For a better overview of driver complexity, other potential drivers should also be assessed, including production strategies, farmer resources, and the precise characteristics of their fields. In addition to biophysical drivers, the assessment of variables related to field accessibility, visibility and protection against animal damage is necessary. In the future, by permitting access to these variables and describing the spatiotemporal patterns of crop location at the watershed scale, remote sensing will help improve our knowledge of farmer decision-making. Conversely, knowledge of farmer decisionmaking and its drivers will improve our understanding of the regionally observed patterns.

A possible operational outcome from this approach and the obtained results is the integration of crop allocation drivers in land use prediction models. This integration will permit the simulation of plausible land use scenarios and the assessment of their subsequent ecosystem services. Overall, the identified drivers should also be perceived as constraints to be considered when defining public and/or 
agricultural policies. The collective rules of crop allocation that were observed in our study indicate that any public policy favouring the spatial alternation of crops at the landscape scale to increase ecosystem services could face difficulties because of the organizational constraints of farmers related to farmland

\section{Acknowledgements}

Financial support for this study was provided by the ANR TRANSMED ALMIRA project (contract ANR-12-TMED-0003-01). The fieldwork was performed within a memorandum of understanding between CRDA Nabeul and INRGREF. We gratefully acknowledge I. Belouafi for participation in the fieldwork. The cooperation of the farmers at Lebna region in providing access to their land and data related to their farms was highly appreciated.

\section{Authorship contributions}

Insaf Mekki: Conceptualization, Methodology, Investigation, Writing - Reviewing \& Editing, Project administration, Funding acquisition.

Jean-Stéphane Bailly: Formal analysis, Writing - Reviewing \& Editing.

Frédéric Jacob: Writing - Reviewing \& Editing, Funding acquisition.

Hichem Chebbi, Tarek Ajmi, Yves Blanca and Abdelaziz Zairi: Investigation.

Anne Biarnès: Conceptualization, Methodology, Investigation, Formal analysis, WritingOriginal draft preparation, Writing - Reviewing \& Editing.

\section{References}

Aubry, C., Biarnes, A., Maxime, F., Papy, F., 1998. Modélisation de l'organisation technique de la production dans l'exploitation agricole : la constitution de systèmes de culture. Études et Recherches sur les Systèmes Agraires et le Développement 31, 25-43.

Anputhas, M., Janmaat, J.A., Craig, F., Nichol, C.F., Wei, X., 2016. Modelling spatial association in pattern based land use simulation models. Journal of Environmental Management 181, 465-476.

Bentley, J.W., 1990.Wouldn't you like to have all of your land in one place? Land fragmentation in northwest Portugal. Human Ecology 18, 51-79.

Benoît, M., Rizzo, D., Marraccini, E., Moonen, A.C., Galli, M., Lardon, S., Rapey, H., Thenail, C., Bonari, E., 2012. Landscape agronomy: a new field for addressing agricultural landscape dynamics. Landscape Ecol. 27, 1385-1394.

Ben Saad, A., Bourbouze, A., 2013. Gestions des terres collectives au Maghreb. Impacts sociaux, économiques et environnementaux de la privatisation : Cas des hautes steppes tunisiennes. Revue des régions arides $30,151-175$.

Ben Slimane, A., Raclot, D, Evrard, O., Sanaa, M., Lefevre, I., Ahmadi, M., Tounsi, M., Rumpel, C., Ben Mammou, A., Le Bissonnais, Y., 2013. Fingerprinting sediment sources in the outlet reservoir of a hilly cultivated catchment in Tunisia. Journal of Soils and Sediments 13, 801-815.

Ben Slimane, A., Raclot, D., Evrard, O., Sanaa, M., Lefevre, I., Le Bissonnais, Y., 2016. Relative contribution of rill/interrill and gully/channel erosion to small reservoir siltation in Mediterranean environments. Land Degradation \& Development 27, 785-797.

Calvo-Iglesias, M. S., Fra-Paleo, U., Diaz-Varela, R. A., 2009. Changes in farming system and population as drivers of land cover and landscape dynamics: The case of enclosed and semi-openfield systems in Northern Galicia (Spain). Landscape and Urban Planning 90, 168-177. 
Caput, 1956. La formation des paysages agraires béarnais. Observations et problèmes. Revue géographique des Pyrénées et du Sud-Ouest 27, 219-242.

Castellazzi, M.S., Matthews, J., Angevin, F., Sausse, C., Wood, G.A., Burgess, P.J., Brown, I., Conrad, K.F., Perry, J.N., 2010. Simulation scenarios of spatiotemporal arrangement of crops at the landscape scale. Environmental Modelling \& Software 25, 1881-1889.

Colin, F., Moussa, R., Louchart, X. 2012. Impact of the spatial arrangement of land management practices on surface runoff for small catchments. Hydrological Processes 26, 255-271.

Deffontaines, J., Thenail, C., Baudry, J., 1995. Agricultural systems and landscape patterns: how can we build a relationship? Landscape and Urban Planning 31, 3-10.

DeLisle, D.,1982. Effects of distance on cropping patters internal of the farm. Annals of Association of American Geographers 72, 88-98.

Demetriou, D., Stillwell, J., See, L., 2013. A new methodology for measuring land fragmentation. Computers, Environment and Urban Systems 39, 71-80.

Fauvel, M., Arbelot, B., Benediktsson, J. A., Sheeren, D., Chanussot, J., 2013. Detection of hedges in a rural landscape using a local orientation feature: From linear opening to path opening. IEEE Journal of Selected Topics in Applied Earth Observations and Remote Sensing 6, 15-26.

Floriani, L., Magillo, P., 2003. Algorithms for visibility computation on terrains: a survey. Environment and planning B: Planning and design 30, 709-728.

Gaubi, I., Chaabani, A., Ben Mammou, A., Hamza, M. H., 2016. A GIS-based soil erosion prediction using the Revised Universal Soil Loss Equation (RUSLE) (Lebna watershed, Cap Bon, Tunisia). Nat Hazards 86, 219-239.

Gonzalez, X.P., Alvarez, C.J., Crecente, R., 2004. Evaluation of land distributions with joint regard to plot size and shape. Agric. Syst. 82, 31-43.

Hervé, D., Genin, D., Migueis, J., 2002. A modelling approach for analysis of agro pastoral activity at the one-farm level. Agricultural Systems 71, 187-206.

Houet, T., Schaller, N., Castets, M., Gaucherel, C., 2014. Improving the simulation of fine-resolution landscape changes by coupling top-down and bottom-up land use and cover changes rules. International Journal of Geographical Information Science 28, 1848-1876.

IAASTD, 2008. Agriculture at a Crossroads. IAASTD synthesis report. International Assessment of Agricultural Knowledge, Science and Technology for Development (IAASTD), Library of Congress, ISBN 978-1-59726-550-8, $106 \mathrm{p}$.

IAO, 2002. Land resources of the Oued Lebna catchment (Tunisia). 20th Course Professional Master: Remote sensing and natural resources evaluation. Istituto Agronomico per l'Oltremare, Florence, Italie, $132 \mathrm{p}$.

Inglada, J., Arias, M., Tardy, B., Hagolle, O., Valero, S., Morin, D., Koetz, B., 2015. Assessment of an operational system for crop type map production using high temporal and spatial resolution satellite optical imagery. Remote Sensing 7, 12356-12379.

Jackson, L.E., Pascual, U., Hodgkin T., 2007. Utilizing and conserving agrobiodiversity in agricultural landscapes. Agriculture, Ecosystems \& Environment 121, 196-210.

Jahel, C., 2016 Analyse des dynamiques des agroécosystèmes par modélisation spatialisée et utilisation d'images satellitaires, cas d'étude de l'ouest du Burkina Faso. Thèse de doctorat de l'Institut des Sciences et Industries du Vivant et de l'Environnement (AgroParisTech), 203 p. 
Joannon, A., Souchère, V., Martin, P., Papy, F., 2006. Reducing runoff by managing crop location at the catchment level, considering agronomic constraints at farm level. Land Degradation and Development 17, 467-478.

Joannon, A., Bro, E., Thenail, C., Baudry, J., 2008. Crop patterns and habitat preferences of the grey partridge farmland bird. Agronomy for Sustainable Development 28, 379-387.

Jouve, A.M. (ed.), 2001. Terres méditerranéennes : le morcellement, richesse ou danger ? Paris. Khartala-CIHEAM, $264 \mathrm{p}$.

Latiri, K., Lhomme, J.P., Annabi, M., Setter, T.L., 2010. Wheat production in Tunisia: Progress, interannual variability and relation to rainfall. Europ. J. Agronomy 33, 33-42.

Latruffe, L., Piet, L., 2014. Does land fragmentation affect farm performance? A case study from Brittany, France. Agricultural Systems 129, 68-80.

Legendre, P., 2000. Comparison of permutation methods for the partial correlation and partial Mantel tests. Journal of Statistical Computation and Simulation 67, 37-73.

Leturcq, S., 2014. La macro analyse des structures agraires à l'épreuve de la micro-analyse d'un terroir. Contraintes communautaire et individualisme agraire dans un finage beauceron (XVII-XXe s.) - Les petits cahiers d'Anatole 14, 1-20.

MARH (Ministère Tunisien de 1'agriculture et des ressources hydrauliques), 2006. Enquête sur les Structures des Exploitations Agricoles 2004-2005. Direction Générale des Etudes et du Développement Agricole, $80 \mathrm{p}$.

Markussen, T., Tarp, F., Thiep, D.H., Tuan, N.D., 2016. Inter- and intra-farm land fragmentation in Viet Nam. UNU-WIDER Working Paper 2016/11, 27 p.

Martinetti, D., Geniaux, G., 2016. Heckman two-stage spatial models for agricultural land use change, AgroMed International Conference, 2016, December 1-2, 2016, Avignon, France.

McCall, M. K., 1985.The significance of distance constraints in peasant farming systems with special reference to sub-Saharan Africa. Applied Geography 5, 325-345.

Mekki, I., Albergel, J., Ben Mechlia, N., Voltz, M. 2006. Assessment of overland flow variation and blue water production in a farmed semi-arid water harvesting catchment. Physics and Chemistry of the Earth 31, 1048-1061.

Millennium Ecosystem Assessment. 2005. http://www.maweb.org/en/index.

Morlon, P., Benoît, M., 1990. Étude méthodologique d'un parcellaire d'exploitation agricole en tant que système. Agronomie 6, 499-508.

Morlon, M., Trouche, G., 2005. Nouveaux enjeux de la logistique dans les exploitations de grande culture. II. L'organisation spatiale des assolements : Exemples et questions. Cahiers Agricultures 14, 205-311.

Pelissier, P., 1953. Les Paysans Sérères. Essai sur la formation d'un terroir du Sénégal. Cahiers d'outre-mer 22, 105-127.

Renes, H., 2010. Grain lands. The landscape of open fields in a European perspective. Landscape History $31,37-70$.

Rizzo, D., Marraccini, E., Lardon, S., Rapey, H., Debolini, M., Benoît, M., Thenail, C., 2013. Farming systems designing landscapes: land management units at the interface between agronomy and geography, Danish Journal of Geography 113, 71-86. 
Schaller, N., Lazrak, G., Martin, P., Mari, J-F., Aubry, C., Benoît, M., 2012. Combining farmer decision rules and landscape stochastic regularities for landscape modelling. Landscape Ecology 27, 433-446.

Sidharthan, R., Bhat, C.R., 2014. Incorporating Spatial Dynamics and Temporal Dependency in Land Use Change Models. Geographical Analysis 44, 321-349.

Sklenicka, P., 2016. Classification of farmland ownership fragmentation as a cause of land degradation: A review on typology, consequences, and remedies. Land Use Policy 57, 694-701.

Schoorl, J. M., Sonneveld, M. P. W., Veldkamp, A., 2000. Three-dimensional landscape process modelling: the effect of DEM resolution. Earth Surface Processes and Landforms 25, 1025-1034.

Sofia, G., Bailly, J.S., Chehata, N., Tarolli, P., Levavasseur, F., 2016. Comparison of Pleiades and LiDAR digital elevation models for terraces detection in farmlands. IEEE Journal of Selected Topics in Applied Earth Observations and Remote Sensing 9, 1567-1576.

Sorel, L., Viaud, V., Durand, P., Walter, C., 2010. Modeling spatiotemporal crop allocation patterns by a stochastic decision tree method, considering agronomic driving factors. Agricultural systems 103, 647-655.

Stoebner, T.J., Lant, C.L., 2014. Geographic determinants of rural land covers and the agricultural margin in the Central United States, Applied Geography 55, 138-154.

Thenail, C., Joannon, A., Capitaine, M., Souchère, V., Mignolet, C., Schermann, N., Di Pietro, F., Pons, Y., Gaucherel, C., Viaud, V., Baudry, J., 2009. The contribution of crop-rotation organization in farms to crop-mosaic patterning at local landscape scales. Agriculture, Ecosystems and Environment $131,207-219$.

Tobler, W., 1970. A computer movie simulating urban growth in the Detroit region. Economic Geography 46, 234-40.

Verburg, P.H., Ton, C.M., de Nijs, T.C.M., van Eck, J.R., Visser, H., de Jong, K., 2004. A method to analyse neighbourhood characteristics of land use patterns. Computers, Environment and Urban Systems 28, 667-690.

Viaud, V., Monod, H., Lavigne, C., Angevin, F., Adamczyk, K., 2008. Spatial sensitivity of maize gene-flow to landscape pattern: a simulation approach. Landscape Ecology 23, 1067-1079.

Watteaux, M., 2005. Sous le bocage, le parcellaire... Etudes rurales [en ligne], 175-176. http://etudesruralesrevues.org/8023.

Webster, R., Oliver, M. A., 2001, Geostatistics for environmental scientists (Statistics in Practice). Wiley Ed., 330 p.

Wohlfahrt, J., Colin, F., Assaghir, Z., Bockstaller, C., 2010. Assessing impact of spatial arrangements of agricultural practices on pesticide runoff: An approach based on regression trees inferred on a database numerically simulated with a physically based model. Ecological Indicators 10, 826-839.

Xiao, R., Su, S., Mai, G., Zhang, Z., Yang, C., 2015. Quantifying determinants of cash crop expansion and their relative effects using logistic regression modeling and variance partitioning. International Journal of Applied Earth Observation and Geoinformation 34, 258-263.

Zitouna-Chebbi, R., Prévot, L., Jacob, F., Mougou, R., Voltz, M., 2012. Assessing the consistency of eddy covariance measurements under conditions of sloping topography within a hilly agricultural catchment. Agricultural and Forest Meteorology 164, 123-135. 